\title{
Macro Monetary Policy and Micro Corporate Behavior
}

\author{
Qifan Xu \\ School of Management, Jinan University, Guangzhou, China \\ Email: xuqifan5218@163.com
}

How to cite this paper: Xu, Q. F. (2020). Macro Monetary Policy and Micro Corporate Behavior. Modern Economy, 11, 740-749. https://doi.org/10.4236/me.2020.113054

Received: February 19, 2020

Accepted: March 27, 2020

Published: March 30, 2020

Copyright $\odot 2020$ by author(s) and Scientific Research Publishing Inc. This work is licensed under the Creative Commons Attribution International License (CC BY 4.0).

http://creativecommons.org/licenses/by/4.0/

\begin{abstract}
The process of monetary policy transmission can be understood as a "macro policy stimulus-microeconomic response-macro output" process, that is, from the process of macro monetary policy control affecting macro output, micro Economies (businesses, households, individuals, etc.) have played a decisive role in responding to monetary policy changes. As early as 1963, scholar Tobin pointed out that corporate asset allocation is a direct reflection of corporate behavior, so it is also of great significance to explore the role of corporate financial asset allocation in the impact of monetary policy on corporate performance. This article reviews the impact of monetary policy on corporate investment and financing behavior, and reviews past research to show the impact of monetary policy on corporate financial behavior.
\end{abstract}

\section{Keywords}

Monetary Policy, Transmission, Corporate Behavior

\section{Introduction}

Macroeconomic policies are policies that affect the entire economy formulated by the government of a country in order to regulate the development of the national economy. Monetary policy has always been an important means of government intervention in the economy. The implementation of monetary policy operating tools also affects enterprises through various transmission mechanisms. This paper reviews the literature from three perspectives: the transmission mechanism of monetary policy, the differences and effects of monetary policy, and the effects of monetary policy on corporate investment and financing. This article intends to analyze the transmission mechanism of monetary policy and the impact of monetary policy on investment and financing of micro-enterprises through a review of previous research. 


\section{The Transmission Mechanism of Monetary Policy}

From the perspective of the transmission mechanism of monetary policy, Kashyap, Stein \& Wilcox (1993) envisage that if faced with austerity monetary policy, banks may mitigate the crisis in the following three ways: reduce loans to enterprises, sell securities they hold, or increase equity capital. And they found that the proportion of securities held by large banks in the United States is lower than that of small banks. At the same time, in the context of tightening monetary policy, raising equity capital is not easy. Therefore, banks facing the crisis are most likely to reduce Business loans. Kashyap, Stein \& Wilcox (1993) provided direct and more convincing empirical evidence for the monetary policy credit transmission mechanism. They used data from Bank of America from the first quarter of 1976 to the third quarter of 1993 to study the transmission mechanism of monetary policy and found that tight monetary policy has a greater impact on small banks and illiquid banks, especially when the regression variable is commercial and industrial loans. Kashyap et al. (1993) found that during the tightening of monetary policy, large enterprises will seek financing channels other than bank loans, such as short-term bonds. In addition to short-term bonds, commercial credit between companies and suppliers can also be used as a substitute for bank deposits. Almeida et al. (2012) found that during the credit crunch period, those companies with a large number of loans due may face renewal freezes and liquidity crises, which will have a greater negative impact on corporate investment and financing, making it too short. The debt maturity constitutes an acceleration mechanism for the impact of tightening credit shocks on micro-enterprises. In addition, the loan term structure is an important means for banks to participate in corporate governance. The shorter the loan term is, the stronger the bank's ability to restrain corporate opportunism will be (Acharya et al., 2011). When the monetary policy shock comes, the bank's risk attitude will change (Borio \& Zhu, 2012). When the statutory deposit reserve ratio rises, commercial banks need to deposit more funds into the reserve Accounts, allowing banks to cut lending levels; when rediscount rates or reloan rates rise, commercial banks' willingness to hold loan assets also declines (Bernanke \& Gertler, 1995). Therefore, when monetary policy tends to be tightened, banks will be forced to reduce the level of stock loans on the asset side due to reduced financing sources and rising financing costs on the bank's liability side (Bernanke \& Blinder, 1992; Kashyap et al., 1993).

\section{The Differences and Effects of Monetary Policy}

In the second section, we analyzed the transmission mechanism of monetary policy. According to previous research, the transmission mechanism of monetary policy does exist. This section is intended to further analyze whether the transmission effects of monetary policy are heterogeneous.

\subsection{Monetary Policy Differences}

From the perspective of monetary policy differences, Cover (1992) confirmed 
the concept of the differential effects of monetary policy by studying the impact of US monetary policy on economic growth. The differential effect of monetary policy is defined as: expansionary monetary policy and tightening monetary policy of the same magnitude have different stimulating and inhibiting effects on the economy. With the continuous research on the difference of monetary poli$c y$, the definition of the difference of monetary policy has also been expanded a lot, forming the horizontal difference effect of monetary policy and the vertical difference of monetary policy. Karras (1996) used data from 18 European countries to find that there is indeed a situation in these countries where the impact of austerity monetary policy on output is greater than that of expansionary monetary policy, especially when interest rates decrease, output is hardly affected. Leu (2006) borrowed from Cover's model to prove that there is also a difference in the effectiveness of Australian monetary policy. In addition, Garibaldi (1997) also started from the perspective of employment to study the difference between the impact of expansionary and contractionary monetary policies on employment, and found that contractionary monetary policies can effectively suppress employment, while expansionary monetary policies are difficult to promote. Aye and Gupta (2012) used India's quarterly data from the second quarter of 1960 to the second quarter of 2011 to test the effects of monetary policy on There is a difference in direction, and they find that positive and negative monetary policy shocks will have different effects on both output and prices. In addition, they also found that compared with the traditional linear VAR model, the use of a nonlinear VAR framework can better characterize the central bank's monetary policy effects.

\subsection{The Heterogeneity of Monetary Policy Effects}

From the perspective of the heterogeneity of monetary policy effects, Garrison and Chang (1979), when studying the effects of monetary policy in different regions, found that the characteristics of industries in each region determine the degree of influence by monetary policy. When studying the regional effects of policies, we noticed the important role played by industrial heterogeneity. It is precisely because of the different industrial capital density distribution in different regions and the inconsistent scale of enterprises that this has caused the effectiveness of monetary policy to be different. This has led scholars to study the differences in monetary policy at the industrial level, that is, the differences in the industrial effects of monetary policy. The research of Blinder (1981) and Christiano et al. (1997) found that the difference in the impact of monetary policy on industries stems from the difference in the impact of monetary policy shocks on industrial profitability. Before the company obtains sales income, it usually pays the costs of fixed asset investment and production factors through borrowing. Due to the different production costs and profit margins of various industries, the impact of changes in nominal interest rates on the profitability of various industries varies greatly., And cause different industries to respond to the same degree of monetary policy. Bernanke and Gertler (1995) use the VAR 
model and use discrete data to study the impact of monetary policy on the consumption of different types of goods, and obtain the conclusion that monetary policy has different effects on industries corresponding to different types of goods. Ganley and Salmon (1997), using British data from 1970 to 1995, used the VAR model to study the impact of British monetary policy on 24 different industries. The impact was relatively large, and the tertiary industry represented by the service industry was relatively less affected by changes in monetary policy. Moreover, the degree of response of different enterprises to monetary policy in the same industry also varies greatly. Small enterprises are more sensitive to monetary policy than large enterprises. Hayo and Uhlenbrock (2000) used the VAR model to study the impact of monetary policy on 28 different industries in German industry. They further confirmed that heavy industries are more sensitive to interest rates than non-durable goods industries. They believe that the inter-industry capital stock The difference is the main reason for the industrial effect of monetary policy. Heavy industries with high capital stocks are affected by changes in monetary policy more than light industries with low capital stocks. Dedola and Lippi (2005) analyzed the panel data of 21 industries in five OECD countries (Germany, Italy, France, the United States, and the United Kingdom), and they found that factors such as company size, financing capacity, and financial cost sharing are explaining the various factors The main reason why industries have varying degrees of reaction to changes in monetary policy. Based on the research based on Dedola and Lippi (2005), Peersman and Smets (2005) expanded the scope of the study, using data from seven countries (France, Germany, Australia, Belgium, Netherlands, Spain, Italy) to study through VAR model The impact of monetary policy on 11 industries, it was found that monetary policy showed significant differences between different industries, and that during economic depression, the impact of changes in interest rates in Europe on output was significantly greater than that during economic prosperity, and they received capital The higher the intensity of the industry, the greater the impact of changes in monetary policy. The industry that produces durable goods is more than three times as strong as the industry that produces non-durable goods. Arnold, Kool \& Raabe (2005) selected relevant data from US states and used VAR models to study the response of manufacturing and non-manufacturing industries to interest rate shocks. The results show that different industries show different degrees of response to interest rate shocks. At the same time, They conducted a more in-depth analysis of the industrial discrepancy effect of monetary policy and they believe that the difference in capital intensity and scale of different industries is an important reason for the difference in the effects of monetary policy industry.

\section{The Impact of Monetary Policy on Micro-Enterprises}

\subsection{The Impact of Monetary Policy on Corporate Financing}

In terms of the impact of monetary policy on corporate financing, Rao Pingui and Jiang Guohua (2010) studied the micro-mechanism of China's monetary 
policy transmission from the perspective of commercial credit and the nature of corporate property rights. The study found that, compared with state-owned enterprises, non-state-owned enterprises The impact on bank credit is even greater. They will use net commercial credit as an alternative financing method. The auxiliary inspection also found that companies with tighter periods will shorten accounts receivable and extend the age of accounts payable. This shows that the nature of property rights of Chinese enterprises is a substitute variable for corporate financing capabilities. Non-state-owned enterprises face credit discrimination and are particularly serious during the currency tightening stage, so they are more likely to use commercial credit as an alternative financing method. Rao Pingui and Jiang Guohua (2013) studied the differences in the allocation of credit resources between state-controlled listed companies and non-state-controlled listed companies under different monetary policy environments in 1998-2008, and the impact of differences in credit resource allocation on the future performance of listed companies. Wu Zhongxin et al. (2013) used Chinese listed companies from 2001 to 2010 as a sample to construct static and dynamic panel data analysis models of corporate capital structure. They studied the impact of credit policies on corporate capital structure and the speed of adjustment. They found that credit policies As a macro-financial factor, it significantly affects the capital structure of an enterprise, and its impact on current liabilities is much greater than long-term liabilities. Among them, the statutory deposit reserve ratio has the most significant effect, followed by the interest rate structure policy of deposit and loan spreads and the capital supervision system of commercial banks, which provides direct evidence for the transmission mechanism of monetary policy confidence. Yu et al. (2014) tested the financing constraint hypothesis of investment efficiency in the article, arguing that the differences between the state-owned and non-state-owned investment efficiency between enterprises in the later period and the investment efficiency of non-state-owned enterprises are lower in comparison It is more caused by frequent monetary policy shocks and non-state-owned enterprise financing constraints caused by government macro-controls. It is believed that the government should reduce intervention so that the capital market can improve the overall efficiency of the economy through resource allocation. Xie Jun, Huang Zhizhong, \& He Cuiru (2013) measured the internal cash flow sensitivity of company investment based on quarterly data of listed companies in Shenzhen and Shanghai from 2002 to 2010, and empirically studied the easing of macro monetary policy through the construction of theoretical models. The investment behavior of enterprises and the effects of financing constraints, at the same time assess the role of optimizing the financial ecological environment from macro monetary policy, and provide evidence for the transmission mechanism of macro monetary policy from the perspective of corporate investment and financing at the micro level. Han Dongping and Zhang Peng (2015) also selected 312 private listed companies in China from 2003 to 2012, researched and analyzed the 
difference in the impact of monetary policy on corporate financing constraints and the impact on corporate investment efficiency. Based on the empirical model of the study, the authors found that companies with different management capabilities face different degrees of financing constraints under different monetary policy easing. Private enterprises with strong external management capabilities can make it easier to relax monetary policy. Xie Jun et al. (2013), from the perspective of regional financial development, used the data of listed companies in Shanghai and Shenzhen every quarter from 2002 to 2010 to evaluate the effect of macroeconomic policies on alleviating corporate financing constraints. They believed that loose monetary policy can promote investment by enterprises, and at the same time, the development of regional financial markets can play a similar role, so as to strengthen the effect of alleviating corporate financial constraints, thereby reducing corporate financial constraints.

\subsection{The Impact of Monetary Policy on Corporate Investment}

In terms of the impact of monetary policy on corporate investment, Xie Jun and Huang Zhizhong (2014) found through empirical research that loose monetary policy promoted corporate expansion and investment, eased corporate financing constraints by reducing the internal cash flow sensitivity of corporate investment, and improved corporate finance. Ecological environment; Jin Qinglu et al. (2012) believes that loose monetary policy fosters a better financing environment for companies to capitalize on the economic law of capital for profit, so that investment opportunities can better guide the company's investment decisions, thereby improving the company's capital allocation efficiency, And this effect is finally reflected in the company's option value. Zhong Kai et al. (2016) constructed a "investment-short-term loan" sensitivity model, which initially verified the existence of certain "short-term and long-term investment" behaviors in Chinese enterprises, and found that "short-term and long-term investment" may increase operating risks and trigger inefficient investments. Ways such as increasing financial distress costs have a negative effect on the company's performance; while a modest increase in monetary policy can not only directly inhibit the "short-term long-term investment", but also reduce the adverse effect of the "short-term long-term investment" on the company's performance Impact plays an indirect role. Yu Ze et al. (2015) research found that in order to evade the control of the scale of desirable loans, commercial banks will use shadow banking to transfer high-risk loans off-balance sheet. This behavior will cause liquidity mismatch, which will cause financial and real economy to be separated, and reduce corporate investment; Yu Kun et al. (2014) studied the impact of monetary policy on corporate investment efficiency and found that in industries with a high degree of external financing dependency, monetary policy shocks will significantly affect the gap between state-owned enterprises and

state-owned enterprise investment efficiency. Yan Xiandong and Zhu Dixing (2018) pointed out that on the one hand, monetary policy affects corporate in- 
vestment by changing corporate financing environment and financing behavior; on the other hand, monetary policy affects corporate investment by affecting overall market expectations and then external demand. Zhang Xizheng, Liu Zhiyuan, Wang Jing (2012) and Yu Bo (2014) divided the impact of monetary policy on corporate investment efficiency into demand-side factors and supply-side factors. From the demand-side analysis, monetary policy can affect the return on investment of enterprises by changing market interest rates, adjust external demand by affecting market expectations, and then influence corporate investment decisions, and ultimately transmit to corporate investment efficiency. From the supply side analysis, when there is information asymmetry, credit shocks will affect the value of corporate mortgage assets and financing capabilities. As the main external source of corporate financing, credit will affect corporate investment behavior (Bemanke \& Gertler, 1995). In terms of empirical research, some scholars have focused on the role of financing constraints in the impact of monetary policy on corporate investment efficiency. Zhang Yichun, Li Wanchun and Peng Jiang (2015) believe that the tightening of monetary policy will exacerbate the shortage of own funds, resulting in insufficient investment by enterprises; due to the lack of supervision of endogenous financing methods, companies with sufficient funds may "snap bottom", Resulting in excessive investment; and loose monetary policy will alleviate the above problems and improve investment efficiency.

\section{Findings/Results with Analysis}

From the literature review, we can know that the current research on the difference of monetary policy is mainly divided into Vertical differences and horizontal differences in monetary policy. Vertical differences mainly study monetary policy in different economies. And the cyclical differences and the differences in monetary policy in different directions; the horizontal differences mainly study the differences between monetary policies in different regions and the differences in the industrial effects of monetary policies. In the study of the differences in monetary policy industry effects, scholars at home and abroad generally agree that there are differences in the effects of monetary policy industry effects, but have not reached a consensus on the extent to which different industries have been affected by changes in monetary policy, especially regarding the three industries. Research conclusions on monetary policy shock response have not yet reached agreement. Scholars' research on the differences in the industrial effects of monetary policy mostly stays at a single level. In fact, there may be multiple levels of superposition in the differences in the effects of monetary policy. First of all, there is indeed a time lag in the implementation of monetary policy to achieve its goals. However, when studying the problem of transmission lag of monetary policy, scholars have ignored the time lag of monetary policy transmission in different industries due to the existence of heterogeneity among industries. There will be differences, and at the same time, scholars have not con- 
sidered the impact of this time-lag difference on the difference in the industrial effects of monetary policy.

In terms of the impact of monetary policy on corporate investment and financing: The method of measuring corporate investment efficiency is mainly indirect; most scholars analyze the impact of monetary policy on corporate investment efficiency from the perspective of easing corporate financing constraints and affecting corporate investment opportunities and investment decisions. Most scholars analyze the impact of commercial credit on corporate investment efficiency from the perspectives of financing constraints and debt governance; the relationship between commercial credit and monetary policy is mainly reflected in the substitution relationship between commercial credit and bank credit, and the impact of commercial credit channels on The weakening effect of the transmission effect of monetary policy; monetary policy and commercial credit will comprehensively affect the investment efficiency of enterprises.

\section{Conclusion}

Economic theory points out that the impact of monetary policy on the economic system is mainly through monetary channels and credit channels. The former is mainly reflected in interest rates, while the latter is mainly reflected in bank credits. Both of these affect the company's financing environment. The impact of monetary policy on corporate financing constraints is mainly reflected in two aspects: On the one hand, loose monetary policy is conducive to enterprises' access to credit rationing. On the other hand, the interest rate level of China's private lending market will also be affected by monetary policy. When monetary policy is tightening, private lending rates will increase, which will further worsen the financing constraints of enterprises; when monetary policy is loose, private market lending rates Reduction will become a source of financing complementary to credit resources. Based on this, on the basis of economic theory, this article reviews the literature on the transmission mechanism of monetary policy to explain the theoretical and display evidence of the impact of monetary policy on the economic system.

On the other hand, as a new field of accounting and financial research, macroeconomic policies and micro-enterprise behaviors have expanded the perspective of research in the field of accounting and finance, and have established a bridge connecting macroeconomic policies and micro-enterprise behaviors. This article takes the macroeconomic policy of monetary policy as the starting point, reviews the impact of monetary policy on micro-enterprise behavior, and uses the two financial issues of investment behavior and financing behavior as sections to show the financial behavior of micro-enterprise by different monetary policies.

\section{Conflicts of Interest}

The authors declare no conflicts of interest regarding the publication of this paper. 


\section{References}

Acharya, V. V., Gale, D., \& Yorulmazer, T. (2011). Rollover Risk and Market Freezes. The Journal of Finance, 66, 1177-1209. https://doi.org/10.1111/j.1540-6261.2011.01669.x

Almeida, H., Campello, M., Laranjeira, B. et al. (2012). Corporate Debt Maturity and the Real Effects of the 2007 Credit Crisis. Critical Finance Review, 1, 3-58. https://doi.org/10.1561/104.00000001

Arnold, I., Kool, C. J. M., \& Raabe, K. (2005). New Evidence on the Firm Size effects in US Monetary Policy Transmission. Discussion Paper Series/Tjalling C (Vol. 5). Koopmans Research Institute.

Aye, G. C., \& Gupta, R. (2012). Are the Effects of Monetary Policy Asymmetric in India? Evidence from a Nonlinear Vector Autoregression Approach. Trends in Applied Sciences Research, 7, 565. https://doi.org/10.3923/tasr.2012.565.571

Bernanke, B. S., \& Blinder, A. S. (1992). The Federal Funds Rate and the Channels of Monetary Transmission. American Economic Review, 82, 901-921.

Bernanke, B. S., \& Gertler, M. (1995). Inside the Black Box: The Credit Channel of Monetary Policy. The Journal of Economic Perspectives, 9, 27-48. https://doi.org/10.1257/jep.9.4.27

Blinder, A. S., \& Fischer, S. (1981). Inventories, Rational Expectations, and the Business Cycle. Journal of Monetary Economics, 8, 277-304. https://doi.org/10.1016/0304-3932(81)90012-X

Borio, C., \& Zhu, H. (2012). Capital Regulation, Risk-Taking and Monetary Policy: A Missing Link in the Transmission Mechanism? Journal of Financial Stability, 8, 236-251. https://doi.org/10.1016/j.jfs.2011.12.003

Christiano, L. J., Eichenbaum, M., \& Evans, C. L. (1997). Sticky Price and Limited Participation Models of Money: A Comparison. European Economic Review, 41, 1201-1249. https://doi.org/10.1016/S0014-2921(97)00071-8

Cover, J. P. (1992). Asymmetric Effects of Positive and Negative Money-Supply Shocks. The Quarterly Journal of Economics, 107, 1261-1282. https://doi.org/10.2307/2118388

Dedola, L., \& Lippi, F. (2005). The Monetary Transmission Mechanism: Evidence from the Industries of five OECD Countries. European Economic Review, 49, 1543-1569. https://doi.org/10.1016/j.euroecorev.2003.11.006

Ganley, J., \& Salmon, C. (1997). The Industrial Impact of Monetary Policy Shocks: Some Stylised Facts. Bank of England. https://doi.org/10.2139/ssrn.74661

Garibaldi, P. (1997). The Asymmetric Effects of Monetary Policy on Job Creation and Destruction. Staff Papers, 44, 557-584. https://doi.org/10.2307/3867466

Garrison, C. B., \& Chang, H. S. (1979). The Effect of Monetary and Fiscal Policies on Regional Business Cycles. International Regional Science Review, 4, 167-180. https://doi.org/10.1177/016001767900400206

Han, D. P., \& Zhang, P. (2015). Monetary Policy, Financing Constraints and Investment Efficiency: Empirical Evidence from Chinese Private Listed Companies. Nankai Management Review, 18, 121-129+150.

Hayo, B., \& Uhlenbrock, B. (2000). Industry Effects of Monetary Policy in Germany (pp. 127-158). SSRN. https://doi.org/10.1007/978-1-4757-6390-4_5

Jin, Q. L., Kong, X., \& Hou, Q. C. (2012). Monetary Policy, Investment Efficiency of Private Enterprises and the Value of Corporate Options. Economic Research, 47, 96-106.

Karras, G. (1996). Are the Output Effects of Monetary Policy Asymmetric? Evidence from a Sample of European Countries. Oxford Bulletin of Economics and Statistics, 58, 267-278. https://doi.org/10.1111/j.1468-0084.1996.mp58002004.x 
Kashyap, A. K., Stein, J. C., \& Wilcox, D. W. (1993). Monetary Policy and Credit Conditions: Evidence from the Composition of External Finance. The American Economic Review, 83, 78-98. https://doi.org/10.3386/w4015

Leu, S. J. (2006). Asymmetric Monetary Policy in Australia. Economic Record, 82, S85-S96. https://doi.org/10.1111/j.1475-4932.2006.00335.x

Peersman, G., \& Smets, F. (2005). The Industry Effects of Monetary Policy in the Euro Area. The Economic Journal, 115, 319-342. https://doi.org/10.1111/j.1468-0297.2005.00991.x

Rao, P. G., \& Jiang, G. H. (2010). Research on the Impact of Monetary Policy on the Interaction between Bank Credit and Commercial Credit. Economic Research, 48, $68-82+150$.

Rao, P. G., \& Jiang, G. H. (2013). Monetary Policy, Credit Resource Allocation and Corporate Performance. Management World, No. 3, 12-22+47+187.

Wu, Z. X., Zhang, Y., \& Zhang, W. (2013). Credit Policy and Corporate Capital Structure: Empirical Evidence from Chinese Listed Companies. Accounting Research, No. 3, 51-58+96.

Xie J., \& Huang Z. Z. (2014). The Impact of Macro Monetary Policy and Regional Financial Development on Corporate Investment and Financing Constraints. Financial Research, 11, 64-78.

Xie, J., Huang, Z. Z., \& He, C. R. (2013). Macro Monetary Policy and Optimization of Corporate Financial Ecological Environment: An Empirical Analysis Based on Corporate Financing Constraints. Economic Review, No. 4, 116-123.

Yan, X. D., \& Zhu, D. X. (2018). Monetary Policy and Corporate Investment and Financing Behavior: A Review Based on the Latest Literature. Financial Review, 10, 94-111+125.

Yu, B. (2014). Does Monetary Policy Affect Enterprise Investment Efficiency?-A Revised Analysis Based on the Dynamic Synergy Perspective of Working Capital. Journal of Guangdong University of Finance and Economics, 29, 4-16.

Yu, K., Li, Z. G., Zhang, X. R., \& Xu, J. G. (2014). The Mystery of Corporate Investment Efficiency: The Financing Constraint Hypothesis and the Impact of Monetary Policy. Economic Research, 49, 106-120.

Yu, Z., Lu, Y. Z., \& Wang, W. D. (2015). Monetary Policy Implementation Model, Financial Mismatch and Investment Constraints of Chinese Enterprises. Management World, No. 9, 52-64.

Zhang, X. Z., Liu, Z. Y., \& Wang, J. (2012). Study on the Double Effects of Monetary Policy on Corporate Investment. Management Science, 25, 108-119.

Zhang, Y. C., Li, W.C., Peng, J. (2015). A Study on the Effect of Debt Governance on Enterprise Investment Efficiency: Empirical Evidence from Chinese Listed Companies. Financial Research, 7, 190-203.

Zhong, K., Cheng, X. K., \& Zhang, W. H. (2016). The Mystery of the Appropriate Level of Monetary Policy and the "Short-Term Loan and Long-Term Investment" of Enterprises. Management World, No. 3, 87-98+114+188. 